\title{
ANALYSIS OF THE EFFECT OF INDONESIAN DEFENSE BUDGET POLICY ON NATIONAL ECONOMIC GROWTH
}

\author{
Posma Sariguna Johnson Kennedy \\ Faculty of Economics - Christian University of Indonesia (UKI) \\ Email: posmahutasoit@gmail.com
}

\section{ARTICLE INFORMATION}

Article history:

Received August 01, 2016

Revised Dec 10, 2016

Accepted May 17, 2017

JEL Classifications

$\mathrm{H} 56$; $\mathrm{H} 61 ; \mathrm{O} 40$

\section{Key Words:}

Budget;

Defense;

Economic

\section{DOI:}

10.21532/apfj.001.17.02.01.04

\begin{abstract}
This study aims to show that budget policy is not only to strengthen defense equipment to the "minimum essential force", but it should not be forgotten that budget policy also provide a multiplier effect on economic growth. The use of a good defense budget can be seen from the extent to which the budget affects the economic growth. This influence is tested by using a single equation of economic growth that is built from the supply side. Regression results of the quartile data of 1991-2010 show that the increase in the national defense budget turns out to have no effect on economic growth and gives negative externalities to the private sector. But, non-defense government budgets provide positive externalities to the private sector. This indicates that the non-defense budgets are able to provide a multiplier effect on the economy, but the defense budget has no effect on the economic sectors directly. So, the defense budget policies must give effect to the national economy, such as increased production with the development of the defense industry to meet the domestic needs of defense equipment.
\end{abstract}

\section{INTRODUCTION}

The Preamble to the Constitution of the Republic of Indonesia 1945 (1945 Constitution) states that after declaring independence from colonial powers, Indonesian people formed the Unitary Republic of Indonesia (NKRI). In the fourth paragraph of the 1945 Constitution, it is mandated that with the presence of the Indonesian state, there is a government that provides protection to the entire nation and the entire homeland of Indonesia, promotes the general welfare, educates the nation, as well as participates in realizing the world order. 
The established government will be able to carry out the duties if the state or nation is in safe condition, so the state is obliged to realize the national security. National security is defined as a national condition and describes the freedom of the state, society and citizens from any form of threats or actions which are influenced by both external and internal factors. National security can also be interpreted as the need to preserve the existence of the state through economic, military and political power and diplomatic development. (Secretary General of the National Defense Council, 2010)

Costs to realize the security and defense are still very much needed as an important activity to date to protect the enormous resources that are always in the face of the interest and uncertainty. Attention on the economic aspects has become very important to make it as a separate study. This interest continues to the economic field development in applying economic methods in matters of defense.

The defense budget is one of important government's policies. So far there have been two developing arguments on the policy of defense expenditure, in which this government expenditure can also give a negative or positive effect on the economy. However, although the relationship bertween the government spending for defense and the economic growth has been studied with a wide range of economic models, the results are still contradictory and unknown for certain whether military spending supports or depresses economic growth.

It is noteworthy that the increase in the defense budget should not be caused by other things but the need for security and economy, such as the inclusion of the interests of the "middleman" in defense programs which can give rise to fraud. The defense expenditures should be able to influence the growth of the national economy.

The entire government budgets are expected to give a multiplier effect on the economy, but special for defense budget, as mentioned earlier, cannot be known for sure whether or not it has an effect on the economy of a country. The purpose of this study is to answer the question of how the effect of government defense expenditure policy on national economic growth. The test results will be analyzed and are expected to be a finding that could be developed in more deeply for a better and fair national defense planning without any abuse.

Based on the framework of formal models built, it is necessary to see the effect of defense expenditure on the economy. Despite the very complex relationship, the test is simplified through a single model of economic growth. Broadly speaking, this study aims to explain the effect of the national defense budget on the economy, through economic growth, by using empirical analysis of the model established.

\section{THEORETICAL FRAMEWORK AND HYPOTHESIS DEVEOPMENT}

The purpose of a state is to maximize the social welfare. With the economic growth, the social welfare is expected to continue to rise. In order to provide social welfare, the development should lead to the creation of a sense of security and comfort among individuals and groups in 
carrying out their activities, so that they can improve their utility to the maximum. To create a sense of security needs defenses to eliminate the threats facing a country.

Development of military power is always in the face of the issue of resource constraints, including national fund sources. Defense expenditure, in fact, has various effects on the economy of a country. From several research conducted by economists, there have been no conclusive opinions on empirical tests that have been conducted in the view of the effect of defense expenditure on economic growth.

The defense budget provided by the government should not be fixated only on the achievement of minimum essential force which tends to be misused in the purchase of defense equipment regardless of whether it can be produced inside or outside the country. However, to see the performance and reciprocal supervision, the use the defense budget should be able to provide optimal effect on the economy. Thus there is no impression that the budget is used on a large scale for the purchase of defense equipment only, without providing any performance to economic growth.

The channel that can be used by the government to influence the economy, especially economic growth, is through fiscal policy. The state can play a role by direct investment funding through the provision of efficient public services so as to encourage economic activities and stimulate long-term investments. Defense spending, as one of the government policies, is expected to have positive effect on the economy. Brasoveanu
(2010) describes that the defense budget policy should be able to influence the economy both directly and indirectly. The defense budget can affect the economy positively through the following channels:

1. Research and development in the defense sector. Research and development in the defense sector can give a positive influence through externalities in the private sector of the economy by stimulating innovations in technology

2. Security. Defense expenditure provides security to maintain stability in the business environment and maintain favorable conditions for attracting foreign investors

3. Demand. The positive effects of defense expenditure can occur through an increase in aggregate demand. Increased demand plays an important role in improving the usability of the unused capitals, reducing unemployment, and improving profitability as well as encouraging a higher investment

4. Labor. Defense expenditure can also develop the skills of most of the population through training and education for the members of the military, thus providing a stimulating effect on growth if it can move the economy toward full employment, forming human resources, maintaining stability, and providing infrastructure

5. Investments. Capital expenditure can provide productive uses, such as uses for the private sector from the transport network that is originally built for military 
purposes. Investment in the defense sector moves positive externalities to the private sector, such as public infrastructure development, spillover of technology, and the formation of human resources.

In addition to positive effects, the defense expenditure of a country can also have negative effects. Therefore, it needs to be managed properly. Brasoveanu (2010) also describes the effects through the channels of the economy as follows:

1. The effect of crowding out. Military expenditure can provide a detrimental effect on the economic growth with the presence of crowding out in the private sector. Military expenditure can be detrimental because it has an effect on investment, savings, human resources, and infrastructure programs. Expansion and the shape of crowding out of an increase in defense expenditure will depend on its use and how to finance it.

2. Opportunity cost. To explain the negative relationship between military expenditure and growth, the economy is focused on the economic opportunity cost of the defense expenditure. Military spending could hinder economic development by reducing savings and allocation of resources, and away from more productive use of the public sector or private sector.

3. Increased taxes. The government budget constraints to increase defense spending can also be financed by other public spending cuts, increased tax, increased loan or an increase in the amount of money in circulation. Various ways of financing to increase defense spending would give further effect which can hit back the economy

4. The efficiency of resource allocation. If military spending is not managed through market mechanisms, it would be likely to cause distortion of relative prices. Implementation of policies to support the military program could interfere with the allocation of resources and economic growth

5. Increased military political power. Defense spending may come not only from the need for security, but also from rent seeking from the complex military industry, thus it can increase armament and military posture that exceed the portions and leads to an arms race or war

Many of these effects occur at once, depending on the level of usefulness and externalities of the defense spending and the effectiveness in addressing the threat. Through certain channels, the defense expenditure has an effect on economic growth.

\section{Framework and Hypothesis}

In this study, the effect of the defense budget on the economy of the country is reviewed by transmission through economic growth. Defense, as a public asset, can only affect the economy through the effect of externalities it produces. To see externalities among the sectors, it is formed the economic growth model developed from the models of Feder 
(1983) -Ram (1993). Further development was done by Cornes and Sandler (1986), Chan (1987), Alexander (1990), Mueller \& Atesoglu (1993), Mintz \& Huang (1990.1991), Ward and Davis (1993), and Heo \& Eger (2005).

Antonakis (1999) states that it is necessary to build a model by dividing the economy into sectors that are aimed at capturing the effect of defense spending on economic growth, although not reviewing the effect of other macro variables. Many different models can be created to capture the interaction between sectors.

In this study, through the development of the model of Mintz \& Huang (1990), it is selected a structure that is considered plausible and useful. By splitting the aggregate $G$ into military expenditure (M) and non-military expenditures $(\mathrm{N})$, the equation is formed into three components, namely the production of the private sector $(\mathrm{P})$, non-military government expenditure $(\mathrm{N})$, and military expenditure $(\mathrm{M})$. In accordance with the previous explanations it can be rewritten:

$Y=C+I+G+(E X-I M)$

$Y=[C+I+(E X-I M)]+N+M$

$Y=P+N+M$ The Mintz-Huang Model (1)

Mintz \& Huang (1990) assume that economy is divided into three sectors of characteristic, namely defense sector (M), non-defense sector $(\mathrm{N})$, and private sector or the rest of the economy (R). These sectors provide externality to the private sector (the rest of the economy). This concept can be seen in the figure below: $\mathrm{Y}=\mathrm{C}+\mathrm{I}+\mathrm{G}+(\mathrm{EX}-\mathrm{IM})$
$\mathrm{Y}=[\mathrm{C}+\mathrm{I}+(\mathrm{EX}-\mathrm{IM})]+\mathrm{N}+\mathrm{M}$

$\mathrm{Y}=\mathrm{P}+\mathrm{N}+\mathrm{M}$ The Mintz-Huang Model (1)

\section{Figure 1}

\section{Externality Effect of Public Sector on}

\section{Private Sector}

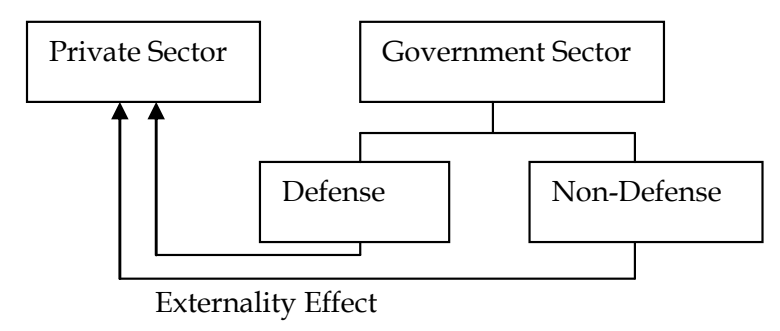

Source: Modeling

One advantage of the formulation of this model is built on the macroeconomic theory that describes the constraints of important deals. The framework of this formulation also provides specification that can separate estimates of the externality effects and productivity differential.

To determine whether there is any effect of government spending in the defense sector on economic growth through the effects of externalities, then it is formed a main hypothesis of the study, namely:

"There is a relationship between the defense budget and the national economy”.

\section{RESEARCH METHODOLGY}

Mintz \& Huang (1990.1991) argue that the externality effects of the defense sector and the non-defense sector are different. Therefore, the externality effects of the defense sector, nondefense sector, private sector are included in separate production functions. To be able to capture externality effects of the military sector 
on private sector, the production function is formally divided into three economic sectors: military, non-military, and private. The establishment of the model begins by assuming that the economy is divided into three characteristic sectors, namely defense sector $(\mathrm{M})$, non defense sector $(\mathrm{N})$, and private sector or the rest of the economy (R), where these sectors provide externalities to the private sector (the rest of the economy). The following are the assumptions built:

a. Production function:

$$
\begin{aligned}
& M=A(t) F\left(L_{m}, K_{m},\right) \\
& N=B(t) G\left(L_{n}, K_{n}\right) \\
& P=C(t) H\left(L_{p}, K_{p}, M, N\right)
\end{aligned}
$$

Where $\mathrm{L}$ is the input of labor, $\mathrm{K}$ is the input of capital, $\mathrm{M}$ is the government spending in military sector, $\mathrm{N}$ is the government spending in non-military sector, and $\mathrm{P}$ is a private-sector spending.

To reflect differences between the externality effects and government sectors, it is assumed that military components and nonmilitary components influence the production of $\mathrm{P}$ sector with a constant elasticity from $\theta_{m}$ and $\theta_{n}$, until it is obtained:

$$
P=C(t) H\left(L_{c}, K_{c}, N, M\right)=N^{\theta_{n}} \cdot M^{\theta_{m}} \cdot \phi\left(L_{c}, K_{c}\right)
$$

Thus the externality effect of the private sector can be demonstrated by:

$\partial P / \partial N=P_{N}=C(t) \theta_{n}(H / N) ; \partial P / \partial M=P_{M}=C(t) \theta_{m}(H / M)$

The size of the elasticity is the intersectoral externality $\theta_{i}(i=n, m)$.

b. Technology Development Level $\left(\Phi_{i}\right)$ :
$A(t) / C(t)=1+\Phi_{m} \quad ; \quad B(t) / C(t)=1+\Phi_{n}$

c. Marginal Productivity $\left(\delta_{i}\right)$ :

$F_{l} / H_{l}=F_{k} / H_{k}=1+\delta_{m} ; \quad G_{l} / H_{l}=G_{k} / H_{k}=1+\delta_{n}$

d. Economic Input: $L=L_{m}+L_{n}+L_{p}$

$K=K_{m}+K_{n}+K_{p}$

\section{e. Total Output}

Total output (total economic output), GDP (Y), is the sum of the outputs from all sectors, that is, $Y=M+N+P$, so the objective function is: $\mathrm{Y}=M+N+P$

The economy grows over time. The equation of production function can be made differentiation with respect to time $t$ of each equation. Differentiation of the total sum of all output, with some mathematical manipulation results in:

$$
\begin{aligned}
& \frac{d Y}{Y}=\lambda+e^{*} \psi_{l}\left(\frac{d L}{L}\right)+e^{*} \psi_{k}\left(\frac{I}{Y}\right) \\
& +\left[\pi_{m}(M / Y)+e^{*} \psi_{m}\right]\left(\frac{d M}{M}\right) \\
& +\left[\pi_{n}(N / Y)+e^{*} \psi_{n}\right]\left(\frac{d N}{N}\right) \\
& +\lambda \pi_{m}\left(\frac{M}{Y}\right)+\lambda \pi_{n}\left(\frac{N}{Y}\right)(9)
\end{aligned}
$$

Or it can be rewritten so as to be able to be analyzed using multiple non linear regression as follows:

$$
\begin{aligned}
\text { growth }_{t}= & \lambda+e^{\lambda} \psi_{l} \text {.gpop }_{t}+e^{\lambda} \psi_{k} \text {.invy } \\
& +\left[\pi_{m}\left(\text { mily }_{t}\right)+e^{\lambda} \psi_{m}\right] . g m i l_{t} \\
& +\left[\pi_{n}\left(n m i l y_{t}\right)+e^{\lambda} \psi_{n}\right] . g n m i l_{t} \\
& +\lambda \pi_{m} \text { mily }_{t}+\lambda \pi_{n} n m i l y_{t}+\delta_{t}
\end{aligned}
$$

From this model it can be seen that the variables involved in influencing economic growth are gpop means population growth, invy means the amount of private investment, gmily 
means the growth of defense sector spending, gnmily means the growth of non-defense sector spending, mily means defense sector spending, and nmily means non-defense sector spending. It can be seen that the equation model of growth established can catch the direct effect of sector $i$ on the economic growth (growth). Parameter $y_{i}$ explains the externality effect of sector $i$, where the growth of sector $i$ gives externality effect on the private sector (the rest of the economy).

\section{DATA ANALYSIS AND DISCUSSION Data}

To improve the defense, after very low in 2008, Indonesia has begun to increase its military budget significantly since 2012, as shown in the Figure 2. The model constructed wants to see if the real defense budget / real GDP, real non-defense budget / real GDP and real private investment / real GDP have an influence on economic growth. The data used for estimation are quarterly data processed from the Ministry of Finance, in the period from 1991 (first quarter) to 2010 (fourth quarter) as many as 80 data, as shown in Figure 3 below.

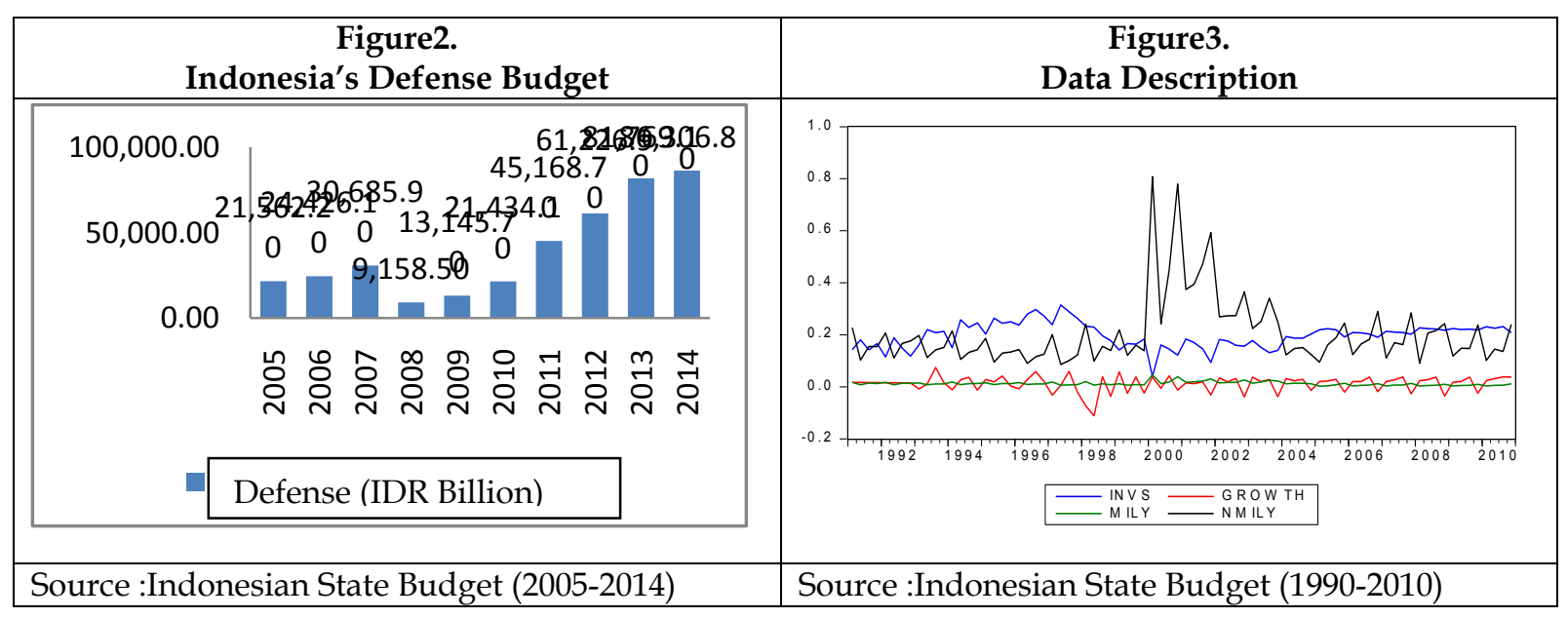

\section{Discussion}

There are two fundamental physical factors in building the strength of the nation: economic factor and defense factor. This means that if the country does not have strong economy and defense, the country will be weakened. The defense budget is determined by the course of the income of a country (GDP), consequently the economic level becomes the decisive factor behind the defense forces. But instead, by having a strong army, it can influence the economic development. Bakrie (2007) wrote that the rise and fall of the defense budget, in general, have an impact on the national economy, therefore economy and defense are major components in building the strength of a nation.

Based on the model that has been built, it can be seen whether the government funds in the form of defense budget can influence economic growth. The sectors of defense and 
Posma Sariguna Johnson Kennedy : Analysis of the effect of Indonesian defense budget .....

Page 49-60

non-defense budgets are also tested whether they have an effect on economic growth and have externality effect on the private sector. In the model there is a dummy variable that is used to distinguish the behavior of the defense budget request model during transitional period of the separation between defense budget and police budget (dummy $=1$ in the period 20002004).

The regression results of the equation can be seen in the following table:

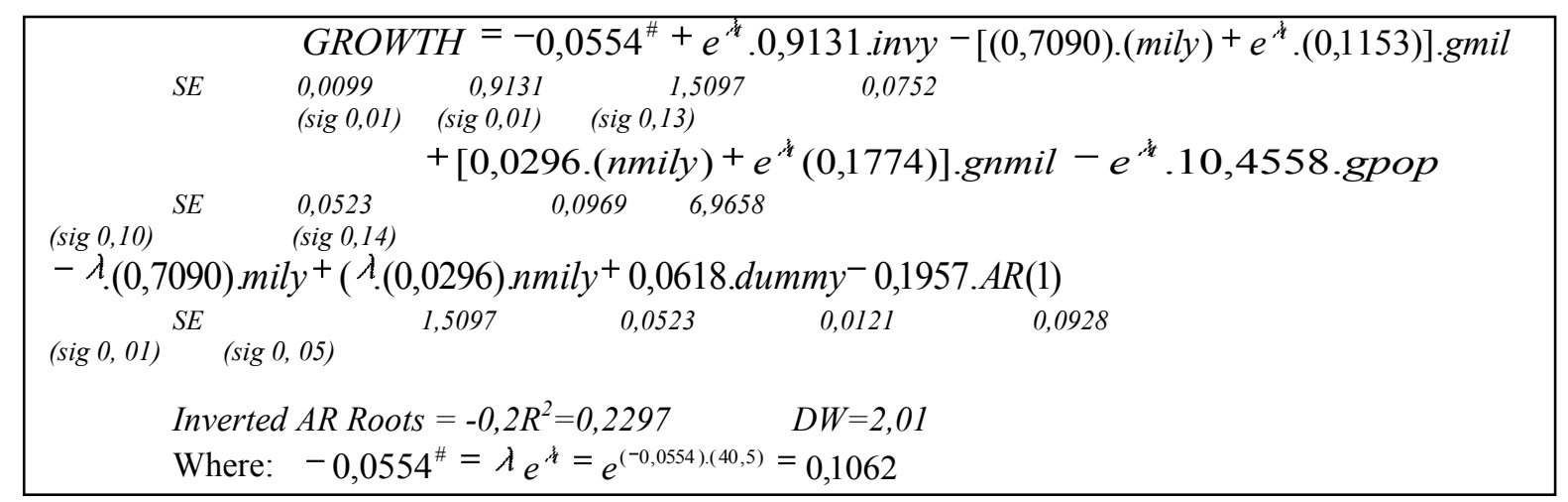

Note: $S E=$ standard error, sig = significance level.

Source: Processed Data

Table 1

Results of the Regression of the Function of Economic Growth

\begin{tabular}{|c|l|c|}
\hline Variable & & Coefficient \\
\hline$\lambda$ & Constant & $-0.0554^{* * *}$ \\
\hline$\psi_{m}$ & Externality effect of defense sector on private sector & $-0.1153^{*}$ \\
\hline$\psi_{n}$ & Externality effect of non defense sector on private sector & $0.1774^{*}$ \\
\hline$\lambda \cdot \pi_{m}$ & The effect of defense sector spending on economic growth & 0.0392 \\
\hline$\lambda \cdot \pi_{n}$ & The effect of non defense sector spending on economic growth & -0.0016 \\
\hline$e^{\lambda t} \psi_{k}$ & The effect of private sector investment on economic growth $\left(t^{\#}=40.5\right)$ & $0.0970^{* * *}$ \\
\hline$e^{\lambda t} \psi_{l}$ & The effect of labor sector on economic growth $\left(t^{*}=40.5\right)$ & $-1.1107^{*}$ \\
\hline
\end{tabular}

Note :

Regression was carried out by OLS method using HAC (Heteroskedasticity and Autocorrelation Consistent Covariance Matrix), standard errors and covariance (Barltlett Kernel, Newey-West) to fix the problem of Heteroskedasticity and Autocorrelation. Sign ${ }^{* * *}$ means the significance level is $1 \%$. For $\mathrm{t}^{*}$ is taken at the midpoint ie $\mathrm{t}^{\#}=40.5$.

Source: Processed Data

Regression of the models are carried out by non-linear least square (NLS) method using HAC (Heteroskedasticity and Autocorrelation
Consistent Covariance Matrix) of Newey, Whitney, and Kenneth so that the results have a better standard error. From the test results of the data, the data on the variable of defense budget 
are real / real GDP and the non-defense budget are real / real GDP showing that the results are not stationary, while the data on other variables are stationary. With the good value of Durbin Watson $(\mathrm{DW}=2.01$ and Inverted AR Roots $<0)$, it is believed that the regression above is not spurious regression. With the different levels of data stationarity between the dependent variable and the independent variable, there is no suspicion of co-integration between the variables involved. The Granger Causality test shows that there is no relationship between the variables (mutual influence) so that this single model can be used.

Here are the test results of the effect of each variable on economic growth:

- Defense sector provides a negative externality effect on the private sector, while non-defense sector provides a positive externality effect on the private sector.

- Defense and non-defense sectors do not affect the economic growth.

- Private investment sector has positive effect on the economic growth, while labor sector (population) has a negative effect on the economic growth.

The empirical results show that the increase in the national defense budget turned out to have no effect on economic growth, but it gives negative externalities to the private sector. It shows that the defense budget has not been able to give a spin-off effect on other sectors and even has not been able to affect Indonesia's economic growth. Non-defense government budget does not affect the economic growth but is able to provide externality effect on the private sector. This shows that the functions of the government budget are still going well.

\section{CONCLUSION AND SUGGESTION}

Defense budget as a government's policy still leaves a negative externality effect. Supposedly, the budget programs can be beneficial to other sectors. It would be better if the defense budget is able to stimulate an increase in production and technology through the defense industry, thus providing a direct influence on economic growth.

What needs to be scrutinized is that the increase in the defense budget should not be caused by other things but the need for security, for example, the inclusion of the interests of rent seekers in defense programs. Besides, the large and disproportionate increase in the defense budget could trigger an arms race among the countries in the strategic environment.

From the findings of this study, it is realized that defense spending has an effect on the economy. Inefficient budget policy will be in vain on any threat level, as it will give the effect of depression on the economy. Therefore, the results of this study should be able to influence the policy makers in determining budget policy with more efficient national defense programs so as to form an effective defense force.

There is a relationship between the defense budget and the economy. Therefore the recommendations are as follows:

- Because there is a relationship between the defense budget and the economy, the government needs to improve the national 
economy by encouraging national production.

- In order to have an impact on economic growth, primary defense equipment should be made in the country through strategic defense industries. Thus there should be a concern of the government to improve and build defense industries

- It is necessary to make a defense force development plan through an adequate budget in order to create a reliable defense capability.

- The existence of government budget limitaitons should be addressed with the equal preparation between defense budget needs and the ability of other budget provision in supporting the national economy

- To increase the use of defense budgets more effectively and efficiently, the government must work hard to eliminate the barriers of themselves, for example by eliminating distortions and inefficiency in the use of state finances, such as in the purchase of primary defense equipment.

\section{REFERENCES}

Alexander, W. Robert J. 1990. The Impact of Defence Spending on Economic Growth: A Multi-Sectoral Approach to Defence Spending and Economic Growth with Evidence from Developed Economies. Defence Economics, Vol.2 : 39-55.

Antonakis, Nicholas. 1999. Guns versus Butter: A Multi-Sectoral Approach to Military Expenditures and Growth with Evidence from Greece, 1960-1993. Journal of Conflict Resolution, Vol. 43 (4) : 501-520.

Atesoglu, H. Sonmez \& Mueller, J. Michael. 1990. Defence Spending and Economic Growth. Defence Economics, Vol. 2(1) : 19-27.

Brasoveanu, Laura Obreja. 2010. The Impact of Defense Expenditure on Economic Growth. Romanian Journal of Economic Foecasting - 4/2010.

Chan, Steve. 1987. Military Expenditures and Economic Performance. In World Military Expenditures and Arms Transfers, edited by the U.S. Arms Control and Disarmament Agency. Washington, DC : Government Printing Office.

Cornes, Richard \& Todd Sandler. 1986. The Theory of Externalities, Public Goods, and Club Goods. Cambridge : Cambridge University Press.

Feder, Gershon. 1983. On Exports and Economic Growth. Journal of Development Economics, Vol. 12 : 59-73. 
Heo, Uk. 1996. The Political Economy of Defense Spending in South Korea. Journal of Peace Reasearch, Vol. 33 (4) : 483-490.

Heo, Uk. \& Eger, Robert J. 2005. Paying for Security-Prosperity Dilemma in the United States. The Journal of Conflict Resolution, Vol. 49 (5) : 792-817.

Mintz, Alex, 1989. Guns Versus Butter : A Disaggregated Analysis. The American Political Science Review, Vol. 83 (4) : 1285-1293.

Mintz, Alex \& Huang, Chi. 1990. Defence Expenditures, Economic Growth and the Peace Dividend. American Political Science Review, Vol. 84 (4) : 1283-1293.

Mintz, Alex \& Huang, Chi. 1991. Guns versus Butter : The Indirect Link. American Journal of Political Science, Vol. 35 (3) : 738-57.

Ram, Rati. 1986. Government Size and Economic Growth: A New Framework and some Evidence from Cross-Section and Time-Series Data. American Economic Review, Vol.76 (1) : 191-203.

Sekretariat Jenderal Dewan Ketahanan Nasional. (2010). Keamanan Nasional, Sebuah Konsep dan Sistem Keamanan bagi Bangsa Indonesia. Jakarta : Author.

Ward, M.D; Davis, D.R. 1993. Sizing up the Peace Dividend: Economic growth and military spending in the US, 1948-1996. American Political Science Review, Vol. 86 (3). 
Posma Sariguna Johnson Kennedy : Analysis of the effect of Indonesian defense budget ..... Page 49-60 